\title{
Defensive strategies of nursing workers in the pediatric emergency room
}

\author{
Estratégias defensivas de trabalhadoras de enfermagem em pronto-socorro pediátrico
}

Fabricio Alberto Lamb ${ }^{1}$, Carmem Lúcia Colomé Beck ${ }^{1}$, Alexa Pupiara Flores Coelho ${ }^{1}$, Susan Bublitz ${ }^{1}$, Fabiele Aozane $^{1}$, Paula Hübner Freitas ${ }^{1}$

Objective: to understand the defensive strategies of nursing workers in the pediatric emergency room. Methods: this is a qualitative research carried out with nine nursing workers from a pediatric emergency room at a federal public university hospital. The data were produced by the focus group and submitted to content thematic analysis. Results: nursing workers reported the need for emotional and affective removal from work, children and families, as well as support in the sense of "fulfilled duty" to avoid suffering. They also search for family, leisure, spirituality/religiosity, psychotherapy and support of the work team for the maintenance of wellbeing and mental health inside and outside the work environment. Conclusion: detachment, rationalization and the search for spaces of refuge appear as individual defensive strategies, while the collaboration and cohesion of the collective of workers represent collective defense strategies.

Descriptors: Emergency Nursing; Occupational Health; Pediatric Nursing.

Objetivo: compreender as estratégias defensivas de trabalhadoras de enfermagem em pronto-socorro pediátrico. Métodos: pesquisa qualitativa, realizada com nove trabalhadoras de enfermagem de um prontosocorro pediátrico de um hospital universitário público federal. Os dados foram produzidos por meio do grupo focal e submetidos à análise temática de conteúdo. Resultados: as trabalhadoras de enfermagem referiram a necessidade de afastamento emocional e afetivo em relação ao trabalho, às crianças e às famílias, bem como o apoio na sensação de "dever cumprido" para evitar o sofrimento. Recorriam, ainda, à família, lazer, espiritualidade/religiosidade, psicoterapia e apoio da equipe de trabalho para a manutenção do bem-estar e da saúde psíquica dentro e fora do ambiente laboral. Conclusão: o distanciamento, a racionalização e a busca por espaços de refúgio despontam como estratégias defensivas individuais, ao passo que a colaboração e a coesão do coletivo de trabalho representam estratégias coletivas de defesa.

Descritores: Enfermagem em Emergência; Saúde do Trabalhador; Enfermagem Pediátrica.

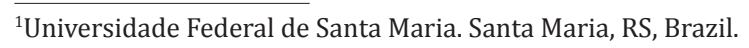




\section{Introduction}

The pediatric emergency room is a gateway to the hospital where people are looking for a quick and resolute response to their most pressing health problems, especially when they cannot find a solution in the basic health care network. The nursing workers have been standing out as those who have more proximity to the patient among the team, bringing a holistic view involving the care process in the biological, mental, emotional and spiritual dimensions of the human being ${ }^{(1)}$.

However, the nursing work in pediatrics can cause suffering to these workers due to the contact with the sickness, suffering or even death of the child; contact with the suffering of parents and other relatives; social issues involving children and their families; child abuse; and violence at work ${ }^{(2)}$. The national and international literature has shown a set of damages to the health of pediatric nursing workers, especially in their psychic health ${ }^{(2-3)}$.

There has been evidence of moral distress among these workers internationally, especially in the nursing team of the intensive pediatric care. The situations causing more suffering are the painful treatments to which children are subjected and the lack of communication in the team ${ }^{(2)}$. At the national level, the incidence of Burnout Syndrome in pediatric oncology nursing workers was evidenced ${ }^{(3)}$.

Work, health, and illness are intrinsically linked and work activity has repercussions on the physical and mental health of workers, and they can be a source of both pleasure and suffering. In this line of thought, this study will be discussed starting from the current of the Psychodynamics of Work, constituted by the French psychiatrist Christophe Dejours. For the Psychodynamics of Work, suffering arises daily in the experience of the subject with his work, being the result of diverse situations that involve feelings of frustration, dissatisfaction, and impotence. Defense strategies or defensive strategies are developed to deal with the suffering arising from man's relationship with work ${ }^{(4)}$.

Defensive strategies consist of psychic mechanisms that workers seek to modify, transform or minimize the perception of the reality that causes them to suffer. They can be elaborated in the individual or collective scope. Defensive strategies can manifest by conformism, individualism, denial, aggressiveness, passivity, among others. Its main purpose is to protect the worker from suffering by preserving his psychic balance $^{(4-5)}$.

It is important to investigate the mechanisms favoring the transformation of suffering into pleasure, or giving meaning to suffering at work, to strengthen the identity and subjectivity of the worker ${ }^{(6)}$. This is compounded by the scarcity of studies that address the perspective of nursing workers about the care given to children and their families in the hospital context ${ }^{(7)}$, ratifying the importance of this study.

In the context of this research, the Research Line "Health/Psychological Suffering of the Worker" of the Graduate Program in Nursing of the Federal University of Santa Maria is highlighted. It has been 15 years studying the relationship between work and mental health, especially in the context of nursing workers. In this course, it was felt the need to know how nursing workers of certain specialties, such as the pediatric emergency room, work to face the labor suffering, a discussion relevant to the field of psychic health of these subjects.

Faced with this questioning, this research was proposed based on the following question: What defensive strategies can be used by pediatric emergency nursing workers? In this perspective, this study aims to understand the defensive strategies of nursing workers in the pediatric emergency room.

\section{Methods}

This is a qualitative study, based on the theoretical reference of Work Psychodynamics. The research was carried out at the Pediatric Emergency Room of a federal public university hospital located in the sou- 
thern region of Brazil. The service works uninterruptedly, in the day and night shifts. It has a work team composed of six nurses, five nursing technicians, and one nursing assistant, totaling 12 workers. The unit has six beds and an emergency room to assist children and adolescents from zero to 14 years old.

This study included workers assigned to the pediatric emergency room for more than six months, a time considered for adaptation. Workers who were away from work for any reason during the survey were excluded. Thus, a total of nine people composed the participants of this study.

Data production was carried out in April 2015 through the technique of the focal group, which comprises an investigative technique that promotes, from the interaction, a broad problematization on a specific theme or focus ${ }^{(8)}$. Altogether, the research demanded the accomplishment of three meetings with, on average, six participants in each meeting.

Each meeting lasted an average of one and a half hours. The meetings were held in an auditorium of the institution, on days and times previously agreed with the participants in the occasion of the invitation to participate in the research. They were moderated by a moderator and conducted with a semi-structured script of triggering questions, linked to the purpose of the study.

The data were audiographed with the consent of the participants and the transcription of the entire content composing the material for analysis. The participants were identified in the transcriptions by the letter W (of the word "worker"), followed by an ordinal number. The data were submitted to thematic analysis of content, developed in the following stages: pre-analysis, material exploration, and treatment of results obtained and interpretation ${ }^{(9)}$. From the analysis, the following thematic categories emerged: The detachment and the rationalization as strategies of the escape from the suffering in the work; The spaces of refuge of the worker; and The coping of work and collective defensive strategies.

The study complied with the formal require- ments contained in the national and international regulatory standards for research involving human beings.

\section{Results}

Regarding the socio-labor data, all participants were women. The age range was between 34 and 55 years old. Most of the participants had between eight and 16 years of work in the institution. Six of the nine participants had children. Four were nurses and five were nursing technicians. There were representatives of all the shifts, with a predominance of the day shift.

Next, the thematic categories from the analysis process will be presented.

\section{Detachment and rationalization as strategies to escape from suffering at work}

The detachment as a way of defense of the workers was present in the testimonies, being used inside and outside the work. "Turning away" from work when at home and keeping some distance from the hospitalized child and their family members were forms of detachment encountered by the participants: I come home and "turn off, I'm off'”' I no longer think [about work ]. Maybe because I'm not a mother, I will not think about it when I go to bed. You suffer less from that. Each has a way of reacting, but I've never been to take home many things (W1).

Also, other data obtained in this study suggest that, for some workers, maintaining a certain affective distance between the hospitalized child and his family helps to minimize suffering: I am not much of "showing of teeth". Sometimes we get bored, but I do not like freedom very much. I think the mother needs to keep some distance, so she does not confuse the assistance with friendship. For me, it is not to get so close, not to suffer, because, later, you accompany the children ... I think it is more a defense for me (W4). I think it has to have a certain [distance], it may be until I'm being cold, but it's my way of working, which I think is right. And even for your protection too, as a person. It's complicated for you to get too involved, then, you end up suffering (W2).

At other times, women workers have emphasi- 
zed as a strategy for distancing suffering, rationalization, that is, support in the sense of duty fulfilled, to have done everything within their reach, which also seems to function as an alleviator of the suffering experienced through rationalization: If you did everything that was within your reach, if you were not negligent, if you gave moral support ... I think so, I gave everything of myself at that time, I did everything that I could (W1). Because at least we did our part, we know that we tried to orient (W3). We fight with the weapons we have. Our part we do. We do our work in the best way possible (W2).

\section{The spaces of refuge of the worker}

This study identified that nursing workers tended to look for refuge spaces in response to the emotional exhaustion experienced in the work activity. As an example, the family space was mentioned as an "escape route" for the participants: You can spend a terrible night, but you leave that door, come home, everything is quiet. I think that's what makes me feel good. The family is my base (W4). I come home and think "my kids are healthy". We have value to that, that the children are healthy, that we are there with them. We can take care of them and enjoy every moment that we are at home (W3).

Also, women workers also search for leisure activities, which were referred as a refuge strategy in relation to attrition and work-related conflicts: [When I get home] I only think about taking a shower and drinking chamomile, with legs up. The time that we have, we enjoy (W3). Listen to music. Flirt (W2). Walk. Flirt. Get out, [read] a bedside book. Walking too, I really like it (W4). Take a bath and a "chimarrão". Go to the mall, going shopping, a movie, music, a book, a walk. A little brother [laughs] (W1).

Another refuge for suffering from work is religiosity, as follows: I pray a lot too. God above all. Our Lady is my protector, I have great confidence. This for me is also a very great relief (W2). I do not forget Our Lady Medianeira, I have her on the side of the bed. Sometimes I begin [to pray] and I sleep, looking at her, so tired that I am. Sometimes I do 24 hours [on duty] ... (W4). I pray too, every day. I ask for physical and mental health, the first thing. Then the rest I can beat it $(\mathrm{W} 1)$.

The workers also emphasized psychotherapy and psychiatric care as a place of refuge. This strategy was considered by them as a resource for the search for the quality of life and the construction of meaning for the experiences of suffering. In this perspective, almost all participants reported having psychological and/or psychiatric monitoring. Many professionals have psychological, psychiatric treatment for depression. Sometimes, it accumulates everything, it is not a single factor, but I think we also need to have a follow-up (W3). I have a psychotherapist and I have a psychiatrist. I have three years of psychotherapy and psychiatrist (W6).

\section{The coping of work and collective defensive strategies}

Finally, the defensive strategies developed and strengthened by the work collective were evidenced. The dialogue within the team, for example, emerges as a "valve of escape" and as an opportunity to express and share feelings and experiences: There, [in the work environment] we feel more family, more intertwined because the people work together more (W7). You could say it's a family. I always felt welcomed inside the team (W8). We do "therapy" on duty. You take care of your colleagues too (W6).

Also, the participants highlighted the good relationship of nursing workers with the medical staff and other workers who work directly or indirectly in the unit. Thus, nursing workers perceive their valued knowledge and have the opportunity to share the responsibilities of the different situations experienced in the daily work with other health workers. Sometimes, they [patient and family] are in a situation ... the mother is very tearful, you go there and try to talk to her mother ... you ask for a psychologist follow-up. When you see, it is a situation where they are very humble ... sometimes they need something and they do not even have relatives here, so we ask the social worker to come and talk to them, see if they can solve anything (T3). I realize that we have this space [group agrees]: so it is a weapon ... in our favor (T5).

Finally, nursing workers identified as a collective strategy the dialogue between the nursing team and the multi-professional team and family members: When something does not go as it should, it must occur, due to many reasons, due to system error, Or lack of knowledge of the routine or 
lack of interest, we discuss it (W3). Everyone works in the same place, everyone has a different opinion, and everyone has the same goal. It's incredible. They diverge, but everyone wants the same thing (W4).

\section{Discussion}

As a limitation of this study, the difficulty of the participation of the nursing team in the focus groups is cited, due to the fact that the work in the pediatric emergency room is uninterrupted. However, it is considered that the results obtained are representative of the team and have resonance with the existing literature, ratifying their relevance. Also, it is emphasized that the focus group allows the understanding of the phenomenon from the collective perspective. In this process, the perceptions of some female workers were more prominent since some of them manifested more than others. Therefore, although the objective of the study was to focus on collective experiences, failure to perform an individual data production step may have limited the understanding of the personal experiences of some participants.

The first category shows how some of the workers' defensive strategies signal attempts to distance themselves from the elements related to suffering at work. Distancing seeks to avoid the emotional and affective involvement of workers in the patients, although there is no guarantee of the effectiveness of such a strategy ${ }^{(10)}$. The separation emerges as a defensive strategy of nursing workers, standing out the concern in separating the professional life from the family life ${ }^{(11)}$.

A study carried out with Iranian nurses showed that they tend to hide their feelings, especially when the family is not fully aware of the child's prognosis ${ }^{(12)}$. Qualitative studies have shown that nurses who care for children understand their attachment to them and their families as an additional source of suffering. For the participants, the empathic response to the sick child added psychological and emotional load to the work performance, especially when the child succumbed to the disease $\mathrm{e}^{(12-13)}$. Therefore, it can be assumed that distancing seeks to avoid the emotional and affective involvement of workers to patients, although there is no guarantee of the effectiveness of such a strategy ${ }^{(10)}$.

For some participants, keeping the family environment as far from work as possible seems to be a form of protection, both for themselves and for the family. This data is similar to the research carried out with US nurses, who sought to alienate their families from situations in their work that involved the suffering and death of children ${ }^{(13)}$.

There is a certain care in hospital nursing workers when they do not share the exhausting experiences of the work environment with their relatives, which can mean an attempt to preserve them and also to forget what is experienced at work ${ }^{(14)}$. However, for Work Psychodynamics, working time and outside work would form a continuum difficult to dissociate, since the worker is an integral subject ${ }^{(5)}$.

Moreover, this category explains rationalization as a defensive strategy used by women workers. The worker rationalizes them to find answers to his suffering, alleviating anguish, fear, and insecurity and, in this way, justifying that there is no reason to suffer since he contributed as much as possible in the care provided $^{(15)}$.

Regarding rationalization, the participants' statements show the feeling of helplessness in the face of illness and death that is inevitable in some circumstances. These data are close to a qualitative study, according to which the active nursing care of the sick child provided the workers with a sense of peace and gave them a sense of the experience of care ${ }^{(13)}$, which is in agreement with the data of this study and indicates that this strategy may be related to coping with the intense situations that make up child care.

Subsequently, the second category evidenced the spaces of refuge of the workers as defensive strategies, highlighting the family space, leisure activities, religiosity, and psychotherapy.

The relationship with the family has a differentiated place in front of the other defense strate- 
gies since the children and the relatives are targets of the assistance provided by these workers, referring to their own experiences. In this sense, listening and family support appear as fundamental factors to face the exhausting situations at work. Leisure activities can also be interpreted as escape spaces, since they are an alternative to relieve stress and suffering, and is a practice usually adopted ${ }^{(14)}$.

Regarding religiosity, there is evidence that nurses consider the approach of spirituality and religiosity essential for the well-being of the professional and even for the accomplishment of a better care. Even in daily work, the use of religiosity and spirituality assists in performing procedures and attending to intercurrences. In this way, its use benefits not only the professional practice but also the personal life of each worker ${ }^{(1)}$.

Together with this, regarding the psychotherapy, a study with nursing workers showed that they feel the need for psychological counseling and participation in self-help groups to make sense and deal with job burnout ${ }^{(14)}$. Emergency nursing work, in particular, has been related to the high percentage of mild mental disorders (anxiety and depression), which would be signaling to the high psychic loads present in the work environment, which is not always perceived by the nursing workers ${ }^{(16)}$.

It should be emphasized that the use of defensive strategies does not prevent the risk of psychic or somatic destabilization of the worker, since they may not be sufficient to compensate for the suffering established. Although the use of defensive strategies is often necessary to alleviate suffering, nursing workers need to identify and recognize this suffering, especially the elements that cause it, so that they are able to mobilize towards the transformation of their work $^{(11)}$.

Finally, the third and last category shows the collective strategies of defense, highlighting how the nursing workers performed the confrontation of suffering in the collective of work. It is in the collective work that one has freedom of speech, where a favo- rable environment is created to seek understanding, affection, harmony, cooperation, and strengthening of the collective, reflecting benefits to the patient ${ }^{(10)}$.

The data found in this study diverged from other scientific evidence that showed the existence of vertical relations and power among workers in the work of nurses in pediatrics ${ }^{(17)}$, which goes in the opposite direction to the cooperation and aggregation of the collective. In this way, the relationship between workers is essential for social relationships since besides strengthening affective bonds, it also stimulates and fosters communication, enabling reflection and critical positioning of workers, developing creativity and harmonization teams.

The data are close to qualitative research carried out with pediatric oncology nurses, according to which the affective connections established between the team, provided emotional support and aided in the processing of their reactions to the suffering. Belonging to a cohesive group meant to have a network in which these workers would find support and empathy ${ }^{(13)}$.

Intervention strategies are needed in the work environment, aiming at health satisfaction of peo$\mathrm{ple}^{(18)}$. These strategies may include creating spaces in which workers can voice their sufferings and collectively build strategies to stay healthy.

The implication of these results is highlighted for the reality of nursing work. The discussion about the psychic health of nursing workers requires that not only the elements involved in suffering be known and discussed but the strategies that can be articulated so that workers are able to stay healthy in their work. In this sense, the understanding of the psychic demands of pediatric emergency nursing workers is reflected in valid knowledge for the establishment of actions for the health of the category. These actions include the structuring of spaces that promote verbalization and discussion about suffering at work and the creation of opportunities for speaking and listening, capable of promoting the breaking of silence and the freedom from suffering. 


\section{Conclusion}

The study enabled to identify that pediatric emergency nursing workers used defensive strategies to deal with labor demands, which included distancing and escaping the elements that cause suffering (such as "detachment from work" and affective detachment), the search for places of refuge (such as family and home, leisure, spirituality/religiosity, and psychotherapy) and rationalization. The collective defense strategies were also evidenced as the workers elaborated tools such as cohesion and collective work, the strengthening and valorization of multi-professional work and the dialogue to solve problems.

\section{Collaborations}

Lamb FA contributed in designing the project, analyzing and interpreting the data and writing the article. Beck CLC contributed in designing the project, analyzing and interpreting data and critically reviewing relevant intellectual content. Coelho APF, Bublitz S, Aozane F and Freitas PH contributed to the essay writing, critical review of the intellectual content and final approval of the version to be published.

\section{References}

1. Nascimento LC, Santos TFM, Oliveira FCS, Pan R, Flória-Santos M, Rocha SMM. Spirituality and religiosity in the perspective of nurses. Texto Contexto Enferm. 2013; 22(1):52-60. doi: http:// dx.doi.org/10.1590/S0104-07072013000100007

2. Trotochaud K, Coleman JR, Krawiecki N, McCracken C. Moral distress in pediatric healthcare providers. J Pediatr Nurs. 2015; 30(6):908-14. doi: http:// dx.doi.org/10.1016/j.pedn.2015.03.001

3. Zanatta AB, Lucca SR. Prevalence of Burnout syndrome in health professionals of an oncohematological pediatric hospital. Rev Esc Enferm USP. 2015; 49(2):251-8. doi: http://dx.doi. org/10.1590/S0080-623420150000200010
4. Dejours C, Abdouchelli E, Jayet C. Psicodinâmica do Trabalho - contribuições da escola Dejouriana à análise da relação prazer, sofrimento e trabalho. São Paulo: Atlas; 2011.

5. Dejours C. A loucura do trabalho: estudo de psicopatologia do trabalho. São Paulo: CortezOboré; 2015.

6. Moraes RD, Vasconcelos ACL, Cunha SCP. Pleasure in work: the place of autonomy. Rev Psicol Organ Trab. 2012; 12(2):217-28

7. Xavier DM, Gomes GC, Salvador MS. The Family caregiver during the hospitalization of the child: coexisting with rules and routines. Esc Anna Nery. 2014; 18(1):68-74. doi: http://dx.doi. org/10.5935/1414-8145.20140010

8. Donaduzzi DSS, Beck CLC, Weiller TH, Fernandes MNS, Viero V. Grupo focal y análisis de contenido en investigación cualitativa. Index Enferm. 2015; 24(1-2):71-5. doi: http://dx.doi.org/10.4321/ S1132-12962015000100016

9. Minayo MC. 0 desafio do conhecimento: pesquisa qualitativa em saúde. São Paulo: Hucitec; 2013.

10. Martins JT, Robazzi MLCC. Defensive strategies used by Intensive Care Unit nurses: reflexion based on the Dejourian view. Cienc Cuid Saude. 2012; 11(supl.):39-46. doi: http://dx.doi.org/10.4025/ cienccuidsaude.v10i5.5071

11. Mariano PP, Carreira L. Defense strategies in the nursing work environment of longstay institutions for the elderly. Rev Gaúcha Enferm. 2016; 37(3):e58587. doi: http://dx.doi. org/10.1590/1983-1447.2016.03.58587

12. Borhani F, Abbaszadeh A, Mohsenpour M, Asadi N. Lived experiences of pediatric oncology nurses in Iran. Iran J Nurs Midwifery Res. 2013; 18(5):34954.

13. Conte TM. The lived experience of work-related loss and grief among pediatric oncology nurses. J Hosp Palliat Nurs. 2014;16(1):40-46

14. Kessler AI, Krug SBF. From pleasure to suffering in the nursing work: the speech of the workers. Rev Gaúcha Enferm. 2012; 33(1):49-55. doi: http:// dx.doi.org/10.1590/S1983-14472012000100007 
15. Monteiro JK, Oliveira ALL, Ribeiro CS, Grisa GH, Agostini N. Mental illness of workers in Intensive Care Units. Psicol Ciênc Prof. 2013; 33(2):36679. doi: http://dx.doi.org/10.1590/S141498932013000200009

16. Magnago TSBS, Beck CLC, Greco PBT, Tavares JP, Prochnow A, Silva RM. An assessment of emergency nurse's work capacity. Rev Eletr Enf [Internet]. 2013 [cited 2017 Jun 13]; 15(2):52332. Available from: http://dx.doi.org/10.5216/ ree.v15i2.15344
17. Leite TMC, Vergílio MSTG, Silva EM. Pediatric nurse's work process: a reality to be transformed. Rev Rene. 2017; 18(1):26-34. doi: http://dx.doi. org/10.15253/2175-6783.2017000100005

18. Telles ACM, Baptista PCP, Vasconcelos LHS, Bernardes CL, Ratier APP. Promoting quality of life at work: experience report of a workshop involving nursing staff. Cogitare Enferm. 2015; 20(3):620-5. doi: http://dx.doi.org/10.5380/ ce.v20i3.38628 